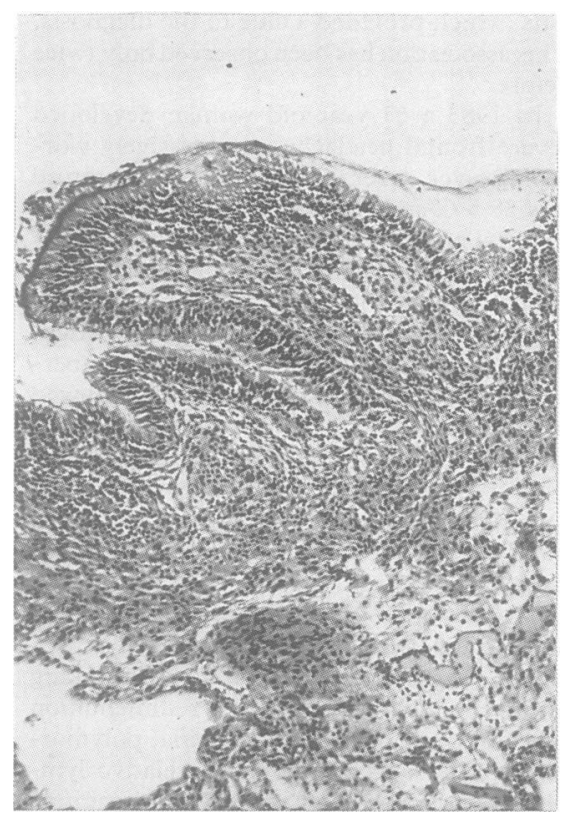

Figure 1 Sphenoidal mucosa exhibiting an extensive inflammatory infiltrate composed mainly by lympho-monocytic cells ( $H E, \times$ 100).

not observed. CT showed an enhancing 7-8 $\mathrm{mm}$ mass in the right posterior part of the sella turcica. A pituitary abscess was suspected and operation was performed.

Transphenoidal exploration showed that the mucous membrane of the sphenoid sinus was thickened with necrotic zones in its right posterior portion. The sellar floor was very thin, the capsule of the mass in the sella was incised and yellow purulent material exuded. Cultures of the purulent material were sterile, but Staphylococcus epidermidis was found in the mucosa of the sphenoid. Histological examination of the tissue removed failed to show evidence of an adenoma or other tumour tissue. The sphenoid mucous membrane was covered by a ciliated columnar epithelium with calciform cells. The underlying chorion was very oedematous, and intensely infiltrated by lympho-monocytic cells (fig 1). A fragment of the sella mass showed an organised conjunctivo-vascular tissue surrounding a central cavity (fig 2), infiltrated by lympho-monocytic cells and polynuclears. Another fragment showed necrotic cells with polynuclear cells, red cells and fibrin deposition. The histopathological diagnosis was compatible with a non-specific chronic sphenoidal sinusitis and an organised pituitary abscess.

Antibiotics and corticosteroid replacement therapy was started, she recovered rapidly; her headaches disappeared gradually and two years after surgery, there has been no recurrence of her symptoms.

Domingue and Wilson reported seven cases of pituitary abscess and reviewed the 50 previously described cases, ${ }^{1}$ since the first description by Simmonds. ${ }^{5}$ Only 29 of these cases had adequate clinical details. Thirteen more cases have been reported by several investigators. Six of those 42 patients had recurrent episodes of purulent or aseptic meningitis. ${ }^{1-4}$ Zorub et al drew attention to the clinical clues that should lead to suspicion of the diagnosis before operation: meningeal signs, fever, blood and CSF leukocytosis. Suspicion of the diagnosis before operation should lead to appropriate antibiotic therapy

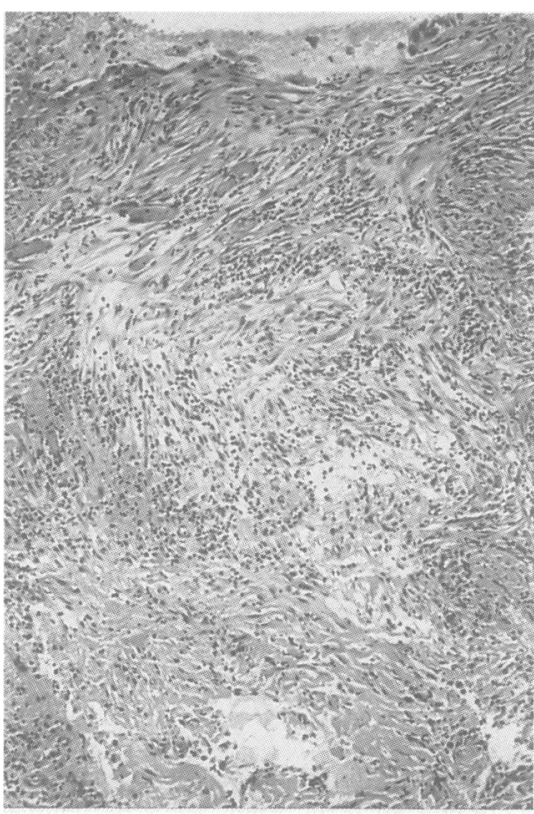

Figure 2 Intrasellar fragment composed by a collagenous tissue more cellular in the outer membrane (upper part), large fibroblasts and oedematous spaces infiltrated by lymphomonocytic cells and polynuclears (inner core of the lesion) $(\mathrm{HE}, \times 100)$.

and the use of a transphenoidal approach, to avoid contamination of the intracranial compartment. The mortality rate of patients who develop meningitis is quite high $(45 \%){ }^{1}$

Our patient had no associated adenoma or tumour, as reported in several instances (10 cases reviewed). ${ }^{6}$ No evidence for an infiltrative lesion (leukaemia, lymphoma, sarcoidosis, granuloma) was found. The purulent material was sterile, that was also the case in $50^{\circ}$ of previous reports. However, cultures for anaerobics were not usually performed. The pathogenesis of the abscess in our patient remains unclear. Chronic sphenoidal sinusitis might have been responsible, but it is not easy to decide if the pituitary abscess was primary or secondary to the presence of sinusitis. Purulent sphenoidal sinusitis can spread to the sella, sometimes with osteomyelitis, sometimes with thrombophlebitis of the cavernous sinus and meningitis. A pituitary abscess may also arise by septic metastasis from a remote source of infection.

This case illustrates that the diagnosis of pituitary abscess should be suspected when progressive panhypopituitarism is associated with recurrent episodes of meningitis and an eroded or enlarged sella. We suggest that skull radiographs should always be obtained when meningitis is established, especially in recurrent episodes.

$$
\begin{array}{r}
\text { DANIEL GUILLAUME } \\
\text { ACHILLE STEVENAERT }{ }^{\star} \\
\text { THIERRY GRISAR } \\
\text { PIERRE DOYEN } \\
\text { MICHEL REZNIK } \dagger \\
\text { Department of Neurology, } \\
\text { Department of Neurosurgery and } \\
\text { Department of Neuropathology, } \dagger \\
\text { University of Liege, CHU, Liege, Belgium }
\end{array}
$$

Correspondence to: Dr Guillaume, Department of Neurology, University of Liège, CHU B33, 4000 LIEGE, Belgium.

1 Domingue JN, Wilson CB. Pituitary abscesses. Report of seven cases and review of the literature. J Neurosurg 1977;46:601-8.
2 Emile J, Degos C, Szekely AM. Méningite aiguë aseptique à liquide clair, avec rechutes, aseptive a buide associec a un abces de la loge hypophysaire A

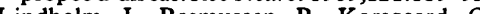

3 Lindholm J, Rasmussen P, Korsgaard $O$. Intrasellar or pituitary abscess. $J$ Neurosurg 1973;38:616-9

4 Rudwan PA. Pituitary abscess. Neuroradiology 1977;12:243-8.

5 Simmonds M. Zur Pathologie der Hypophysis Verh. Dtsch. Ges Pathol 1914;1 7:208-12.

6 Zorub DS, Martinez AJ, Nelson PB, Man-Ta L. Invasive pituitary adenoma with abscess formation: case report. Neurosurgery 1979;5:718-22.

\section{Transient global amnesia following} ingestion of chloroquine

Transient global amnesia (TGA) is a temporary disturbance of short term memory of unknown aetiology. Neither an epileptic ${ }^{1}$ nor a vascular, transient ischaemic cause have been confirmed. It has rarely been described after ingestion of clioquinol derivatives, ${ }^{2}$ and possibly triazolam, ${ }^{3}$ after trauma, with tumours of the temporal lobe associated with migraine. ${ }^{+}$

A 62 year old healthy business man was planning to leave for Zaire on the day of his admission. He had used chloroquine on a journey to Central America two years previously, apparently without ill effect. The morning of his departure, he took $300 \mathrm{mg}$ of chloroquine. Three hours later he felt ill. He could remember nothing about his travelling plans. He did not recall the name of the colleague he was planning to travel with. $\mathrm{He}$ forgot things which had happened only minutes before.

On admission, he was oriented to time and place. He could remember his birthday and some events from the past. However, his immediate recall was considerably disturbed. This spontaneously subsided about three hours later. Routine biochemical and haematological parameters were normal. A cerebral CT scan, cardiovascular examination that included ECG and digital intravenous angiography of the extracranial portion of carotid and vertebral arteries, were normal.

Peak values of chloroquine are reached after three hours. Although TGA has never been associated with this product, its chemical structure is related to clioquinol, which has been. The retinopathy and neuromyopathy of chloroquine are well known. Admittedly, these unwanted effects occur after ingestion of large doses for extended periods. Although a chance association cannot be excluded, we suspect that the ingestion of chloroquine in this man caused or triggered the appearance of TGA.

PATRICK CRAS JEAN-JACQUES MARTIN Laboratory of Neuropathology, Born-Bunge Foundation and Department of Neurology, University of Antwerp,

Universiteitsplein 1, Wilrijk, Belgium

1 Cole AJ, Gloor P, Kaplan R. Transient global amnesia: the electroencephalogram at onset. Ann Neurol 1987;22:771-2.

2 Mumenthaler M. Transient global amnesia after clioquinol: five personal observations from outside Japan. J Neurol Neurosurg Psychiatry 1979;42:1084-90.

3 Morris $\mathrm{HH}$ and Estes ML. Traveler's amnesia. Transient global amnesia secondary to triazolam. JAMA 1987;258:945-6.

4 Miller JW, Petersen RC, Metter EJ, Millikan $\mathrm{CH}$, Yanagihara $\mathrm{T}$. Transient global amnesia: clinical characteristics and prognosis. Neurology (Minneapolis) 1987;37:733-7. 